\title{
Developing Image of Higher Education Performance
}

\author{
Uyu Wahyudin ${ }^{1}$, Ridwan El Hariri' ${ }^{2}$, Deni Darmawan ${ }^{3}$ \\ ${ }^{1}$ Doktoral Nonformal Education, Faculty of Education, Indonesia Universiy of Education, Bandung, Indonesia \\ ${ }^{2}$ Directorate of Cooperation and Business, Indonesia University of Education, Bandung, Indonesia \\ ${ }^{3}$ Educational Technology Departement, Faculty f Education, Indonesia University of Education, Bandung, Indonesia \\ Email: udinpls@yahoo.co.id, elhariri@gmail.com, diestry2005@yahoo.com
}

Received January 15, 2013; revised March 15, 2013; accepted April 15, 2013

Copyright (C) 2013 Uyu Wahyudin et al. This is an open access article distributed under the Creative Commons Attribution License, which permits unrestricted use, distribution, and reproduction in any medium, provided the original work is properly cited.

\begin{abstract}
The study focused on Pattern Analysis Relationships between Basic Element Institutional Excellence in Education with a focus of the study: What is the actual profile of the basic elements of excellence of educational institutions, influence leadership, strategic planning, as well as students and focus stakeholders, focus staffs and faculty in order to develop the image Parahyangan University (UNPAR) performance by reference to the Performance Excellence Criteria for Education. The method used a qualitative approach and quantitative approach [1] with two models using qualitativequantitative approaches, namely: two-phase design, dominant-les dominant design, and mixed methodology design. Respondents and the information in this study are a lecturer and head of the University.
\end{abstract}

Keywords: Performance; Institution; Leadership; Managemengt Strategic

\section{Introduction}

The idea of improving the quality of human resources through higher education is considered up to date and effective up to now. Through an empiric observation, a country with an advanced higher education is, in general, found to have an advanced life in its society, for instances, America, Japan, and Australia. The population in these three countries is considered to have an advanced life since they have advanced universities. The United States of America, for instance, has Harvard University, Iowa University, and University of Syracus. Japan has Tokyo University, Kyoto University, and Tohoku University, whereas, Australia has Australian National University, University of Melbourne, and University of New South Wales.

The indication of the close relationship between the low of human resource quality, as indicated by the low quality of the university, is also seen in Indonesia. Sayed, et $a l$. are assisted by ten experts and the experts in the World Bank explicitly report the failure of education in Indonesia in "Education in Indonesia: From Crisis to Recovery". The indications such as the high drop-out level, the low level of continuing study, the low participation level, and the low achievement level are the indicators found in the national education which have not been satisfied yet. The report which consists of 174 pages and seven chapters has only shown one key word "unsatis- factory" in relation to the implementation and the results of education (Supriyoko, 2001a) [2].

In accordance with the observation and research done by the World Bank in Indonesia, Makmun (2001) concludes that there are at least three main factors which have caused the low quality of education in Indonesia [3]. First, the policy which tends to emphasize on the educational production function or the input-output analysis approach ignoring the process of the educational implementation. Second, the implementation of education tends to be centralistic which is positioning the educational institution as the front-liner in the educational field as the technical implementation unit which is much depending on the complex bureaucratic decisions which are not relevant with the objective conditions of the local the educational institutions. Third, the participation of the society, especially parents, in the educational implementation is very restricted on input endorsement such as financial support which has not touched the aspect of educational process, the decision making, monitoring, controlling, and accountability. As the consequence, the management of education does not seem to have any responsibility to report on the educational results to parents and the related parties.

Referring to the explanation above, in order to find out the solution of the low quality of higher education in Indonesia which directly impacts the quality and competi- 
tiveness of human resources as the consequences of the educational system, a total reformation of a paradigm of the overall management subsystems is needed in the higher education which makes it possible to do some innovations and healthy competitions (Tilaar, 1999) [4]. The new paradigm covers basic reformation in philosophical nature, vision, mission, and strategic development in order to be more adaptive in responding the strategic higher education environment which influences the institutional processes to run their functions and roles. The reformation should be arranged in a policy of higher education development that focuses on academic, human resources, learning facility, research and development, public services, organization and management, students, national and international cooperation, communication and culture, belief and faithful, postgraduate studies, and financial expenses. According to Gaffar (2001) such a policy on the higher education development is known as an image development. The image itself is actually a representation of all information about a higher education that has been processed, organized, and saved in an individual memory [5].

The researcher is therefore interested in doing a research on the higher educational performance as the representation of its quality, efficiency, relevance and implementation to the policy in developing the image of higher education performance.

This research has applied a mixed methodology design since both of the qualitative and quantitative approaches are integratedly used and are supporting from one to another. The implementation of such an approach is methodologically correct (Cresswell, 1994). Sugiyono [6] states that qualitative and quantitative approaches can be applied together to do a research on the same objects with different purposes. The quanlitative approach was applied to find the hypothesis, while the quantitative approach was applied to examine the hypothesis.

In this research, the qualitative approach is aimed to: 1) investigate and study the actual profile of Unpar performance and its relevance to the Performance Excellence for Education Criteria, and 2) investigate and study the alternative model of policy strategies in developing the image of excellent higher education performance in the future which is responsible to any changes and market needs based on the considerations of Unpar educational experts, educational management experts, the Association of Indonesian Private Higher Education (APTISI), users of graduates, management in faculty level, lecturers, students, alumni, parents and public figures.

While the quantitative approach is aimed to test the hypothesis which specifically relates to the four aspects: 1) to investigate and study the influence of leadership, strategic planning, students and stakeholders focus influence on the staffs and faculty focus in developing the image of Unpar performance; 2) to investigate and study the influence of leadership, strategic planning, students and stakeholders focus on the management process in developing the image of Unpar performance; 3) to investigate and study the influence of leadership, strategic planning, students and stakeholders focus on the staffs and faculty focus in developing the image of Unpar performance; and 4) to investigate and study the relative contribution of the brain center to the driver triad, work core, and outcomes in developing the image of Unpar performance.

This research has applied a descriptive method to study, describe, and estimate data and see the correlation among the data. Best [7] clarifies that a descriptive method sees a relationship between variables, tests a hypothesis, or tests a theory. Furthermore, Best argues that this method is appropriate to be applied in the social science studies. This research not only described the phenolmena but also tested a hypothesis, therefore, it was also applied in an explanatory survey. As the consequence, the research variables need to be stated into measurable indicators to describe the needed data and information.

In order to obtain the required data, an in-depth interview and a nine scale questionnaire were applied. The interview data were analyzed qualitatively and data from the questionnaire were analyzed quantitatively through statistical techniques of row analyses. The row coefficient is calculated and tested by using double regression approach. Then, the row coefficient is resulted from the standardized beta.

The results showed: 1) Performance Unpar in many cases already referred to the Performance Excellence Criteria for Education was launched by the Baldrige National Quality Program, 2) Leadership, strategic planning, and students and stakeholder focus have positive effects on staffs and faculty focus and management processes to construct the Unpar performance, 3) education experts, education management, Association Private Higher Education Indonesia (APTISI), the user graduates, academicians and public figures Unpar give consideration leadership practices of strategic planning; students and stakeholder focus; staffs faculty focus; management processes; Information and analyses; organizational performance results.

The research problem is then broken down into the following research questions:

1) How is the actual profile of the basic elements of excellence of the educational institution in developing the image of Unpar performance in accordance with the Performance Excellence for Education Criteria?

2) How do the leadership, strategic planning, students and stakeholders focus influence the staffs and faculty focus in developing the image of Unpar performance?

3) How do the leadership, strategic planning, students 
and stakeholders focus influence the management processes in developing the image of Unpar performance?

4) How do the leadership, strategic planning, students and stakeholders focus, staffs and faculty focus, and management processes influence the organizational performance results in developing the image of Unpar performance?

5) How does the brain center contribute to the driver triad, work core, and outcomes in developing the image of Unpar performance?

6) How does the alternative model of policy strategices develop the image of higher education performance excellence which is responsive to any changes and needs of the market based on the following considerations: experts of education, experts of educational management, Association of Indonesian Private Higher Education (APTISI), users, academic and staff members (management at the faculty level, faculty members, students, alumni, and parents) of Unpar and public figures of the society?

\section{Result and Discussion}

\subsection{Model of Strategic Developing}

In order to find the solution on the low quality of the Indonesian higher education which directly impacts the quality and competitiveness of human resources, according to Tilaar (1999) [8], requires comprehensive and fundamental change of paradigm of higher education management in terms of philosophy, vision, mission, and development strategy to be more adaptive to the strategic environment of the higher education which is changing and impacts the overall institutional processes in implementing the primary functions and roles. This kind of fundamental change should be made through a policy on the higher education development, according to Gaffar (2001) [9], known as image development. Such a condition is also applied in a private higher education.

The tracer study on the websites about the excellence performance of higher education in the international context, many countries have formed a reliable agency as the quality assurance for higher education, e.g. European Foundation for Quality Management (EFQM) in Europe, Quality Assurance Agency (QAA) in the United Kingdom, Australian University Quality Agency (AUQA) in Australia, Akkreditieringstrat in Germany, National Quality Assurance and Accreditation Agency (NQAAC) in Cairo, International Model of Quality Assurance and Accreditation (IMQAA) in New Zealand, and International Network for Quality Assurance Agency (INQAA). Since 1987, the United States of America (USA) has even launched the Baldrige Award Criteria for Education under The American Society for Quality (ASQ) management.

Among the existing model of strategies in developing the quality performance of higher education, this research has decided to rely on the Performance Excellence in Education developed by Baldrige Award Criteria for Education (Blazey, et al., 2001) [10]. According to these criteria, the excellence performance of higher education has a series of basic criteria which can be classified into four categories: driver triad, work core, brain center, and outcomes. Driver triad consists of leadership, strategic planning, and students and stakeholders focus. Work core covers staffs and faculty focus and management process. Brain center consists of information and analysis, while outcomes refer to the organizational performance results.

\subsection{The Work Core Refers to Main Organizational Duties in Developing Staffs, Lecturer and Management Processes}

The positional excellence of private higher education is very important in creating the image of quality performance which then influence the achievement of its marketing performance. Amri (2005) [7] approves his research that the positional excellence directly influences on the performance achievement. Meanwhile, Yulius (2004) [8] states that the image of quality performance of private higher education significantly influences on the active number of total students (marketing performance). Furthermore, Karnadi (2005) [9] shows his research that the image of institution influences on the loyalty of the students.

An image is formed based on someone's impression and experience which can develop it into a mental attitude (Alma) [10]. Alma (1998) further explains that there are eleven variables which can create the positive image of a higher education: lecturer, library, educational technology, consultant bureau, sport activity, art activity, religious activity, parents' visit to campus, distribution of graduates to work market, campus publication, and alumni. Among the eleven variables, the quality lecturer is admitted to be the key resource in creating the image.

Based on the explanation above, it is concluded that the development of institutional quality performance is very important to improve the image of institution. There are many ways to develop the image of higher education performance. One of the most strategic ways to develop the image is through benchmarking and franchise to the national and international higher education institutions showing their excellent performance, e.g. the Performance Excellence in Education developed by Baldrige Award Criteria for Education (Blazey) [11] to empirically study the influences of the criteria of institutional excellence on its performance. It is expected that this way can create a holistic and adaptive model appropriate with the institutional environment. This model can also be implemented to the private higher education institutions. 
Blazey, et al. [11] indicates four basic elements of excellence in a higher education institution: Driver Triad, Work Core, Brain Center, Outcomes. The theoretical framework is visually presented in Figure 1.

The driver triad includes leadership, strategic planning and students and stakeholders focus. The leader uses this process to design purpose, evaluate progress, make decision related to resources, and do corrective actions. The work core refers to main organizational duties in developing staffs, lecturer and management processes.

\subsection{The Description of Unpar Performance}

Leadership: the organizational culture of Unpar is run based on the motto "Pursuing knowledge based on divinity to serve the society". In accordance with the organizational culture of Unpar, it indicates that the organization is formulated, implemented, and controlled by values of belief in God, truth, openness, and contribution. The leadership in Unpar is participative and puts priority on the reliability of system in the management of the organization. The leadership gives more emphasis on functional dimension than figures.

Strategic Panning: Unpar has primary development plans up to the year 2012 with its vision: "Becoming an International Academic Community to Improve the Fulfillment of Human Values". The development plans are classified into 15 points: 1) vision, mission, objective and target; 2) governance; 3) institutional management; 4) students and counseling service; 5) human resource; 6)

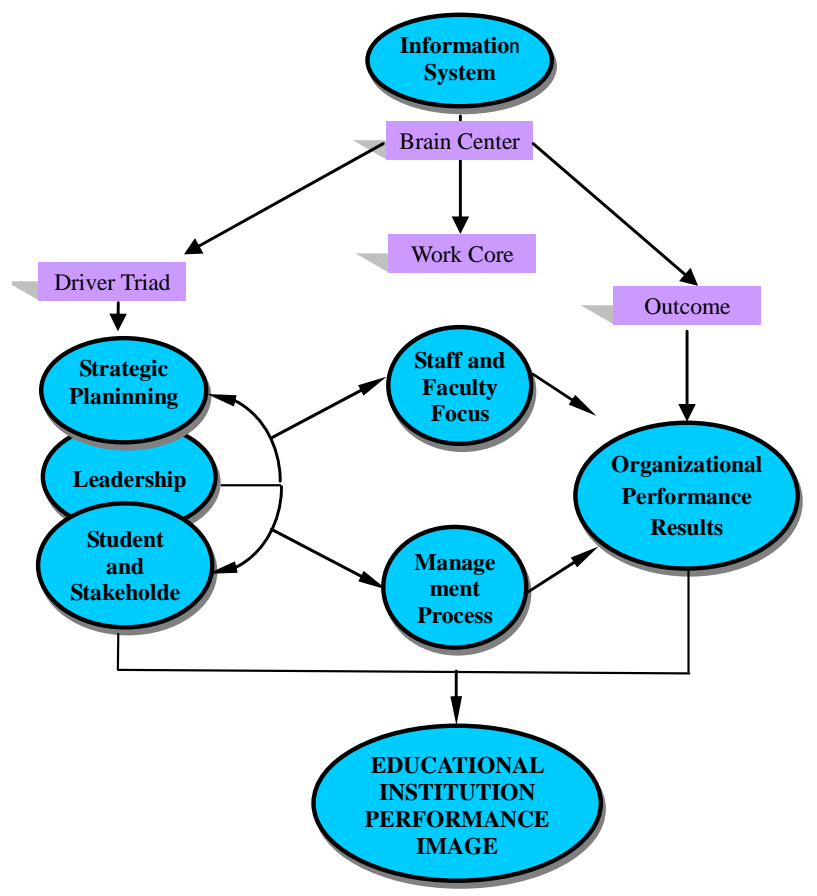

Figure 1. Organizational duties in developing staffs, lecturer and management processes. finance; 7) infrastructure; 8) curriculum; 9) academic atmosphere; 10) learning process; 11) research and publication; 12) public service; 13) quality improvement and control system; 14) information system; and 15) sustainability. Each development plan is completed by an analysis of its strengths and weaknesses and clearly indicates its objectives and indicators of success in its projected time.

Students, stakeholder, and market focus. Unpar concerns with quality, especially the quality of students who are going to study at the university. The university is very selective in recruiting new students assuming that the process and output of education will be better when its input has good quality. Open organizational culture in Unpar is shown through respecting different views, opinion, feeling, belief, ability, and skills in order to improve and maintain relationship between campus community and stakeholders.

Information and Analysis. Each decision made by the management of Unpar is based on data and information about the organizational performance derived from each unit and level and the information analysis is viewed as the primary instrument for the improvement of performance and competitiveness of the university. The primary principles that are held by Unpar in developing the information management are: 1) the data and information can be easily understood by students, stakeholders, and parents; 2) the data can be accessed and shared by students, stakeholders, and parents everywhere and anytime; 3) the data are kept their security and confidential; 4) post-service is provided for the students, stakeholders, and parents who encounter problems related to the available data.

Faculty and staffs focus. The policies made by Unpar are: 1) giving authority to the lecturers to access data for making decisions related to their profession, including those related to curriculum, learning process, and responsibility; 2) appreciating every input from the staffs and lecturers for the revision of the work plans; 3) giving awards to the lecturers and staffs who complete their duties faster and spend expenses lower than the estimated cost; 4) involving the lecturers and staffs to participate in developing awarding system and evaluating the system periodically; 5) reinforcing the potential lecturers and staffs for the bases of organizational values; and 6) recruiting the lecturers and staffs who have clear vision to develop Unpar without being influenced by corruption, collusion, and nepotism. The quality development for lecturers has been implemented since 1970s by giving opportunity to the lecturers to continue studying in the country and overseas. The quality development of administrative staffs, technician, laboratory assistant, librarian, and other supporting staffs is done through in-house training, outside training, and formal education. 
Process Management. Unpar avoids the implementation of expansive programs, such as the increase of student body or the number of study programs and concentrates more on the consolidative programs, such as formulation and improvement of management and regulations in various areas and threshold programs in terms of quantity, quality, and human resources in different fields. The process of management should be made effective and efficient and should not be bureaucratical as indicated in the organizational structure determined by the government which is considered to be inefficient. Therefore, the management is simplified in its structural positions and uses its own terminology known as core and support and they are assisted by several directors. Such a simple organizational structure adopts the concept of business management which is proven to be effective.

Organizational Performance Result. The evaluation system for students's learning achievement, regulations on the evaluation of learning achievement and completion of study, and determination of judicium in Unpar is improved continuously. The system of learning evaluation is determined by comparing the competency of the graduates and the targeted competency, productivity of learning, data on learning achievement of the students and the completion of the students in their study, and the judicium of the graduates. The index of students achievement is increasing from year to year viewed from the data provided by the university to show the profile of the students achievement which is classified based on individual, study program, department, faculty, and university levels and its comparison to the other universities. Unpar always avoids "academic accident", e.g. giving score or rewards without any clear academic bases since it will hurt the values of education.

In accordance with the implementation of new service paradigm, Unpar pays attention more seriously on students and stakeholders satisfaction. Public accountability is shown on the level of students and stakeholder satisfac- tion taken from various resources and work period. The cash flow of Unpar is completed by financial details from each unit and the projection of income and espenses within eight years to come. In general, each of the income and expense components is increasing every year. These data are supported by alternative programs offered to public.

In regard to the effectiveness of organization which refer to the principle of transparancy, it shows that the university performance is getting more and more satisfying. It is indicated by the increasing number of study programs or departments which get better accreditation, efficiency of time, energy, and other operational expenses, the fulfillment of legal aspect from each policy of the university, and faster services provided to students and stakeholders. The data are collected through several methods without any parts of the data to be hidden and they are updated every year. The data are derived from day to day university operation and therefore the progress can be seen anytime.

1) The dimensions of leadership, strategic planning, students and stakeholders focus influence on the staffs and faculty focus. The result of row analysis can be seen in the following Table 1.

Simultaneously, the influence of leadership, strategic planning, students and stakeholders focus on the staffs and faculty focus is $69.06 \%$. Among the three variables, the biggest influence on the staffs and faculty focus is the students and stakeholders focus (18.74\%), followed by leadership (7.24\%), and strategic planning (3.42\%).

2) Dimensions of leadership, strategic planning and students and stakeholders focus, both individually and simultaneously, positively influence on the management process. The result of row analysis is presented in the following Table 2.

Simutaneously, the influence of leadership, strategic planning, students and stakeholders focus on the management process is $88.17 \%$. Among the three variables, the biggest influence on the staffs and faculty focus is the students and stakeholders focus (30.03\%), then followed by leadership (6.20\%), and strategic planning (4.12\%).

3) The dimensions of leadership, strategic planning, students and stakeholders focus, staffs and faculty focus, and management process, both individually and simultaneously, positively influence on the organizational performance results. The result of row analysis can be seen in the following Table 3.

The influence of leadership, strategic planning, students and stakeholders focus, staffs and faculty focus, and management process on the organizational performance results is $90.82 \%$. Among the five variables, the biggest influence on the organizational performance results is leadership (6.35\%), then followed by management process $(5.62 \%)$ students and stakeholders focus (5.48\%), staffs and faculty focus (3.53\%) and strategic planning (1.25\%).

4) The dimension of brain center positively correlates with the driver triad, work core, and outcomes. Result of the calculation of correlation coefficient can be presented in the following Table 4.

The research shows that brain center significantly has positive correlation with the driver triad, work core, and outcomes in Unpar. This result indicates that the better the brain center, the better the driver triad, work core, and outcomes. On the other hand, the less the condition of the brain center of a higher education institution, the less the driver triad, work core, and outcomes. The quality of brain center has the highest correlation with the outcomes and work core compared with that of the driver triad. The score of the outcomes determined by brain 
Table 1. Result of raw coefficient test of leadership, strategic planning, students and stakeholders focus to staffs and faculty focus.

\begin{tabular}{cccc}
\hline Exogenous Variable & $\boldsymbol{P}$ & $\boldsymbol{p}$-value & Interpretation \\
Leadership $\left(X_{1}\right)$, & 0.269 & 0.000 & Significant \\
$\begin{array}{c}\text { Strategic Planning }\left(X_{2}\right), \\
\text { Students and Stakeholders Focus } \\
\left(X_{3}\right)\end{array}$ & 0.185 & 0.017 & Significant \\
Total & $\mathbf{0 . 8 3 1}$ & $\mathbf{0 . 0 0 0}$ & Significant \\
\hline
\end{tabular}

Notes: The Endogenous Variable in the model is Staffs and Faculty Focus $\left(X_{5}\right)$. Critical value of $\mathrm{H}_{0}$ rejection in this research is $\alpha=0.05$.

Table 2. Result of row coefficient test of leadership, strategic planning, and students and stakeholders focus to management process.

\begin{tabular}{|c|c|c|c|}
\hline Exogenous Variable & $\boldsymbol{P}$ & $p$-value & Interpretation \\
\hline Leadership $\left(X_{1}\right)$, & 0.249 & 0.000 & Significant \\
\hline Strategic Planning $\left(X_{2}\right)$, & 0.203 & 0.001 & Significant \\
\hline Students and Stakeholders Focus $\left(X_{3}\right)$ & 0.548 & 0.000 & Significant \\
\hline Total & 0.939 & 0.000 & Significant \\
\hline
\end{tabular}

Notes: The Endogenous Variable in the model is Management Process $\left(X_{6}\right)$. Critical value of $\mathrm{H}_{0}$ rejection in this research is $\alpha=0.05$.

Table 3. Result of row coefficient test of leadership, strategic planning, students and stakeholders focus, staffs and faculty focus, management process to organizational performance results.

\begin{tabular}{cccc}
\hline Exogenous Variable & $\boldsymbol{P}$ & $\boldsymbol{p}$-value & Interpretation \\
\hline Leadership $\left(X_{1}\right)$, & 0.252 & 0.000 & Significant \\
Strategic Planning $\left(X_{2}\right)$, & 0.112 & 0.043 & Significant \\
Students and Stakeholders Focus $\left(X_{3}\right)$ & 0.234 & 0.001 & Significant \\
Staffs and Faculty Focus $\left(X_{5}\right)$ & 0.188 & 0.003 & Significant \\
Management Process $\left(X_{6}\right)$ & 0.237 & 0.022 & Significant \\
Total & $\mathbf{0 . 9 5 3}$ & $\mathbf{0 . 0 0 0}$ & Significant \\
\hline
\end{tabular}

Table 4. Result of correlation coefficient test between brain center and driver triad, work core, and outcomes.

\begin{tabular}{|c|c|c|c|c|c|}
\hline \multirow{2}{*}{\multicolumn{2}{|c|}{ Dependent Variable }} & \multicolumn{3}{|c|}{ Brain Center $\left(X_{4}\right)$} & \multirow[t]{2}{*}{ Interpretatior } \\
\hline & & $\boldsymbol{R}$ & $r^{2}$ & $p$-value & \\
\hline & Leadership $\left(X_{1}\right)$, & 0.737 & 54.32 & 0.000 & Significant \\
\hline \multirow{2}{*}{$\begin{array}{l}\text { Driver } \\
\text { Triad }\end{array}$} & $\begin{array}{c}\text { Strategic } \\
\text { Planning }\left(X_{2}\right),\end{array}$ & 0.839 & 70.22 & 0.000 & Significant \\
\hline & $\begin{array}{c}\text { Students and } \\
\text { Stakeholders } \\
\text { Focus }\left(X_{3}\right)\end{array}$ & 0.883 & 77.97 & 0.000 & Significant \\
\hline \multirow{3}{*}{$\begin{array}{l}\text { Work } \\
\text { Core }\end{array}$} & $\begin{array}{l}\text { Staffs and Faculty } \\
\text { Focus }\left(X_{5}\right)\end{array}$ & 0.869 & 75.52 & 0.000 & Significant \\
\hline & $\begin{array}{l}\text { Management } \\
\text { Process }\left(X_{6}\right)\end{array}$ & 0.926 & 85.75 & 0.000 & Significant \\
\hline & Outcomes & 0.900 & 81.00 & 0.000 & Significant \\
\hline
\end{tabular}

Notes: Critical value of $\mathrm{H}_{0}$ rejection in this research is $\alpha=0.05$. center is $81.00 \%$. In the work core, the score of management process determined by the brain center is $85.75 \%$ and score of the staffs and faculty focus determined by brain center is $75.52 \%$. Meanwhile, in the driver triad, score of the students and stakeholders focus determined by the brain center is $77.97 \%$ and scores of the strategic planning and leadership also determined by brain center respectively are $70.39 \%$ and $54.32 \%$.

\subsection{Alternative Model of Policy in Developing the Image of Higher Education Performance}

In accordance with the considerations of educational experts, educational management experts, the Indonesian association of private universities, stakeholders, campus community, parents, students, and public figures on standard practices of excellence performance of higher education, it is identified that: 1) the driver triad which covers the leadership, strategic planning, students and stakeholders focus; 2) the work core covering the faculty and staffs focus and the process; 3) brain center/information and analysis; and 4) outcomes/organizational performance results should be implemented in the institutions of private higher education in order to make those institutions to have excellent performance [12].

In general, there are four quality development models of educational institution performance, they are: transformative model, engagement model of program quality, university learning model, and model for a responsive university. Baldridge model is an example of transformative model. The result of analysis on the strengths and weaknesses of Balridge model shows that the direct adoption of Baldridge model in the implementation of policy strategies in improving the quality of higher education performance is not appropriate. Therefore, alternative models of quality policy development strategies which are relevant with the context and pedagogical values of the Indonesian higher education are needed.

\section{Conclussions}

The conclusions of the research can be formulated as follows:

1) In many ways, the performance of Unpar has met the Performance Excellence for Education Criteria launched by The Baldrige National Quality Program.

2) Leadership, strategic planning, students and stakeholders focus have significant and positive correlation with staffs and faculty focus and management process in developing the image of Unpar performance. Simultaneously, leadership, strategic planning, students and stakeholders focus, staffs and faculty focus, and management process have significant and positive correlation with organizational performance results in developing the image of Unpar performance. In addition, the brain center has 
relatively significant and positive contribution to driver triad, work core, and outcomes in developing the image of Unpar performance.

3) Educational experts, educational management experts, association of the Indonesian private higher education, stakeholders, campus community (faculty management, lecturers, students, alumni, and parents) and public figures consider that the practices of leadership strategic planning; students and stakeholders focus; staffs and faculty focus; management process; information and analyses; and organizational performance results which are explored by by Blazey, et al. (2001) are considered relevant and can be used as the bases for references in developing an excellent performance higher education in the future. Therefore, policies made by Unpar in developing an excellent performance higher education in the future should refer to these practices.

4) A holistic model of policy strategies in developing the higher education performance is needed in order to develop an excellent performance of higher education which is responsive to any changes, appreciating the characteristics of higher education institutions, and building commitment to educational values.

The implications of research for the management and the implementation of higher education are: 1) the university has to maintain the existing conditions and continuously develop the university by referring to the leadership, management process, students and stakeholders focus, staffs and faculty focus, and strategic planning supported by reliable brain center; 2) the quality assurance institution in the higher education has to design a model of performance evaluation by adopting Baldrige model to diagnose the strengths and weaknesses and its efforts in the performance development; 3) the further researchers should conduct comparative study on the determining factors of excellent performance in various higher education which has different characteristics to see its adaptibility and feasibility in the implementation of a holistic model to improve the performance of a higher education institution.

\section{REFERENCES}

[1] J. W. Creswell, "Research Design: Qualitative and Quantitative Approaches,” Sage Publications, London, 1994.

[2] K. Sugiyono, "Metode Penelitian Kuantitatif, Kualitatif, dan R \& D,” Alfabeta, Bandung, 2006.

[3] Best, "Research in Education," Prentice Hill, New Delhi, 1982.

[4] K. Supriyoko, "Menuju PT Indonesia Berkelas Dunia,” Pikiran Rakyat, 21 Juni 2001.

[5] Tb. A. S. Makmun, "Manajemen Bimbingan dan Konseling Berbasis Sekolah,” Makalah Disajikan Dalam Seminar BK Yang Diselenggarakan Jurusan PPB FIP UPI Bersama ABKIN Pada Tanggal, 15 Agustus 2001.

[6] H. A. R. Tilaar, "Beberapa Agenda Reformasi Pendidikan Nasional Dalam Perspektif Abad ke-21,” Indonesia Tera, Magelang.

[7] M. F. Gaffar, "Membangun Citra Baru untuk Era Baru" Pidato Rektor pada Upacara Dies Natalis ke-47 UPI, Bandung, 26 Oktober 2001.

[8] Blazey, et al., "Insight to Performance Exellence in Education 2001: An Inside Look at the 2001 Baldridge Award Criteria for Education,” ASQ Quality Press, Winconsin, 2001.

[9] Amri, "Pengaruh Lingkungan Bisnis Ekternal dan Penerapan Strategi Keunggulan Bersaing Melalui Pencapaian Posisi Pasar Terhadap Kinerja Perusahaan (Suatu Kajian Pada Pasar Swalayan di Kota Bandung),” UNPAD, Bandung, 2005.

[10] Y. Yulius, “Pengaruh Bauran Pemasaran Jasa Pendidikan terhadap Citra PTS serta Implikasinya terhadap Jumlah Mahasiswa Aktif (Studi pada PTS yang memiliki Fakultas Ekonomi di DKI Jakarta),” UNPAD, Bandung, 2004.

[11] M. S. Karnadi, "Pengaruh Kualitas Jasa, Citra Institusi, dan Kepercayaan Mahasiswa terhadap Nilai Jasa Pendidikan Tinggi serta Dampaknya pada Loyalitas Mahasiswa,” UNPAD, Bandung, 2005.

[12] B. Alma, "Manajemen Pemasaran dan Pemasaran Jasa," CV Alfabeta, Bandung, 2005. 